\title{
Teaching NeuroImages: Glossopharyngeal Nerve Focal Pressure Atrophy in Glossopharyngeal Neuralgia
}

Luying Li, MD, PhD, and Heng Zhang, MD, PhD

Neurology ${ }^{\circledR} 2021 ; 96: 769-770$. doi:10.1212/WNL.0000000000011321

Figure 1 Preoperative MRI Showing Neurovascular Conflict in Glossopharyngeal Neuralgia
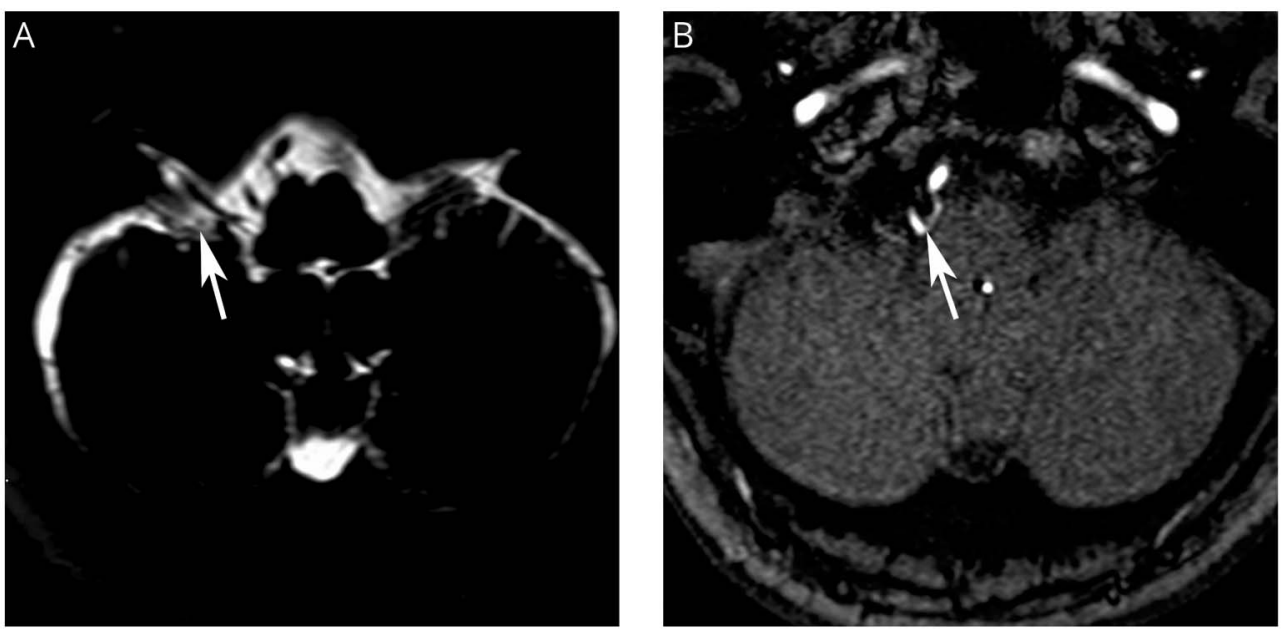

(A) MRI with fast imaging employing steady-state acquisition indicates neurovascular conflict (arrow) of the crania nerve IX (CN IX). (B) T1 MRI with gadolinium enhancement demonstrates the conflicting artery loop (arrow) of posterior inferior cerebellar artery (PICA), a branch from the vertebral artery (VA).

A 57-year-old woman presented with a 1-year history of frequent, sharp, prickling pain in the right oropharynx, often triggered by swallowing or talking. Oxcarbazepine, pregabalin, and mecobalamin were tried but pain relief was not satisfactory. MRI with fast imaging employing steady-state acquisition indicated neurovascular compression of the cranial nerve IX (figure 1). ${ }^{1}$ Glossopharyngeal neuralgia was diagnosed and microvascular decompression was performed. The patient achieved complete relief of pain immediately after surgery. Evident focal nerve volume loss above the compressing artery was observed during operation (figure 2), highlighting mechanic force as the cause for glossopharyngeal neuralgia.

\section{Study Funding}

No targeted funding reported.

\section{Disclosure}

The authors report no disclosures relevant to the manuscript. Go to Neurology.org/ $\mathrm{N}$ for full disclosures.

\section{Correspondence}

Dr. Zhang

zhangheng@scu.edu.cn

\section{MORE ONLINE}

$\rightarrow$ Teaching slides

links.lww.com/WNL/ B298 
Figure 2 Intraoperative Snapshot Showing Glossopharyngeal Nerve Focal Pressure Atrophy in Glossopharyngeal Neuralgia
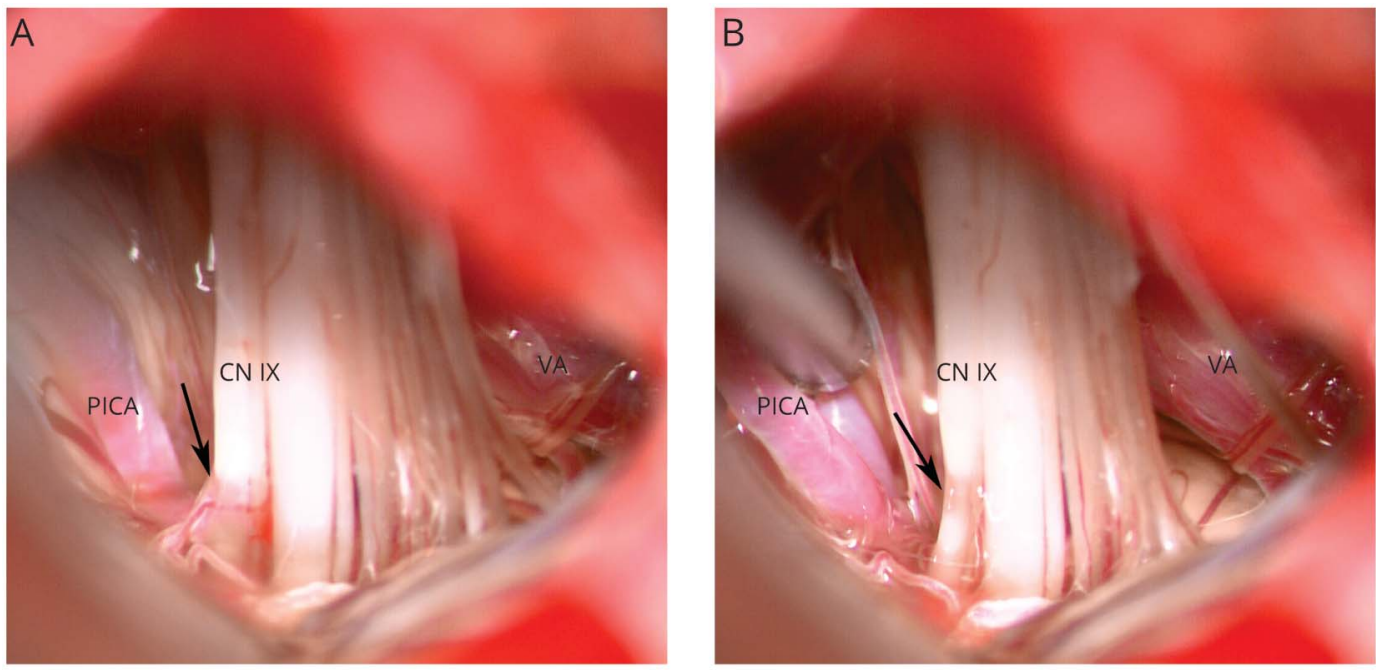

(A) Focal pressure atrophy manifesting as a semitransparent notch (arrow) in front of the conflict artery. (B) The culprit artery loop was held to the left of the nerve; focal pressure atrophy (arrow) is visually evident.

Appendix Authors

\begin{tabular}{lll}
\hline Name & Location & Contribution \\
\hline $\begin{array}{l}\text { Luying Li, } \\
\text { MD, PhD }\end{array}$ & $\begin{array}{l}\text { West China of Sichuan } \\
\text { University, Chengdu }\end{array}$ & $\begin{array}{l}\text { Drafted the manuscript, } \\
\text { assisted in data collection }\end{array}$ \\
\hline $\begin{array}{l}\text { Heng Zhang, } \\
\text { MD, PhD }\end{array}$ & $\begin{array}{l}\text { West China of Sichuan } \\
\text { University, Chengdu }\end{array}$ & $\begin{array}{l}\text { Data collection, revision of } \\
\text { manuscript }\end{array}$ \\
\hline
\end{tabular}

\section{Reference}

1. Truini A, Colonnese C, Manfredi M. Glossopharyngeal nerve contrast enhancemen in recent-onset glossopharyngeal neuralgia. Neurology 2015;84:1283.

\section{Disputes \& Debates: Rapid online correspondence}

The editors encourage comments on recent articles through Disputes \& Debates:

Access an article at Neurology.org/ $\mathrm{N}$ and click on "MAKE COMMENT" beneath the article header. Responses will be posted as rapidly as possible.

Before submitting a comment to Disputes \& Debates, remember the following:

- Disputes \& Debates is restricted to comments about articles published in Neurology within the last 8 weeks

- Read previously posted comments; redundant comments will not be posted

- Your submission must be 200 words or less and have a maximum of 5 references; the first reference must be the article on which you are commenting

- You can include a maximum of 5 authors (including yourself) 


\section{Neurology}

\section{Teaching NeuroImages: Glossopharyngeal Nerve Focal Pressure Atrophy in Glossopharyngeal Neuralgia \\ Luying Li and Heng Zhang}

Neurology 2021;96;769-770 Published Online before print December 4, 2020

DOI 10.1212/WNL.0000000000011321

\section{This information is current as of December 4, 2020}

\section{Updated Information \& Services}

References

Subspecialty Collections

Permissions \& Licensing

Reprints including high resolution figures, can be found at: http://n.neurology.org/content/96/16/769.full

This article cites 1 articles, 1 of which you can access for free at: http://n.neurology.org/content/96/16/769.full\#ref-list-1

This article, along with others on similar topics, appears in the following collection(s):

\section{All Pain}

http://n.neurology.org/cgi/collection/all_pain

Neuropathic pain

http://n.neurology.org/cgi/collection/neuropathic_pain

Other trauma

http://n.neurology.org/cgi/collection/other_trauma

Information about reproducing this article in parts (figures,tables) or in its entirety can be found online at:

http://www.neurology.org/about/about_the_journal\#permissions

Information about ordering reprints can be found online:

http://n.neurology.org/subscribers/advertise

Neurology ${ }^{\circledR}$ is the official journal of the American Academy of Neurology. Published continuously since 1951, it is now a weekly with 48 issues per year. Copyright () 2020 American Academy of Neurology. All rights reserved. Print ISSN: 0028-3878. Online ISSN: 1526-632X.

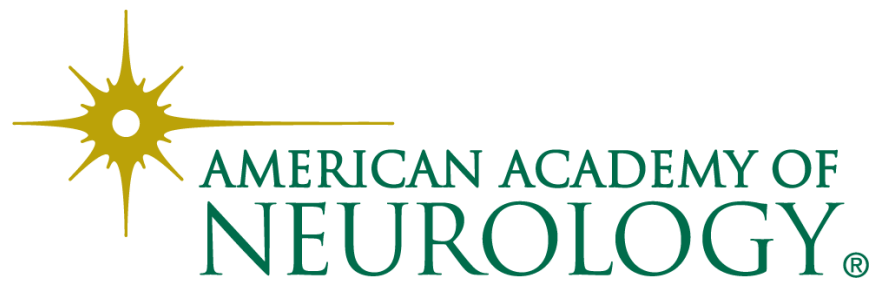

